\title{
THE TAXATION OF OUT-OF-STATE TANGIBLE PROPERTY
}

\author{
BORIS I. BITTKER†
}

THE abandonment by a majority of the Supreme Court, in recent years, of an earlier majority's ill-starred attempt to find in the Fourteenth Amendment a prohibition against multiple state taxation of intangibles evoked law review comment in profusion. ${ }^{1}$ In declaring that this prohibition, once seen so clearly by Mr. Justice McReynolds, ${ }^{2}$ was only a mirage, ${ }^{3}$ the Court did not so much establish a new horizon

$\dagger$ Assistant Professor of Law, Yale School of Law; formerly Chief of the Liquidation Section of the Alien Property Custodian Office.

1. See, for example, Lowndes, The Tax Decisions of the Supreme Couth, 1938 Term (1939) 88 U. of Pa. L. Rev. 1; Nash, And Again Mulliple Taxation? (1938) 26 GEo. L. J. 288; Traynor, State Taxation and the Supreme Court, 1938 Term (1939) 28 CaLIF. L. REv. 1; Tweed and Sargent, Death and Taxes are Certain-But what of Domicile (1939) 53 HAnv. L. REv. 68. For discussion of the earlier law, see Merrill, Jutrisdiction to Tax-Another Word (1935) 44 YALE L. J. 582; Rodell, A Primer on Interstate Taxation (1935) 44 YALE L. J. 1166. A comprehensive bibliography may be found in MAGILL aNd MAGUiRE, CASES ON THE LAW OF TAXatTon (3d ed. 1940) $401 \mathrm{n}$.

2. "A very large part of the country's wealth is invested in negotiable securities whose protection against discrimination, unjust and oppressive taxation, is matter of the greatest moment. ... [E]xisting conditions .... imperatively demand protection of choses in action against multiplied taxation. . . ." Farmers Loan \& Trust Co. v. Minnesota, 280 U. S. 204, 212 (1930), overruling contrary views expressed by Mr. Justice Holmes in Blackstone v. Miller, 188 U. S. 189 (1903), which apparently had been regarded as authoritative as recently as 1925. Frick v. Pennsylvania, 268 U. S. 473 (1925). See Sachs, The Saga of Blackstone v. Miller: A Study in Mulliple State Taxation in Mathews aND HaRT (eds.), Essays in Political Science (1937) 231. Mr. Justice McReynolds read this "imperatively demand[ed] protection" into the Fourteenth Amendment by a tour de force, saying "we can find no sufficient reason for saying that they [intangibles] are not entitled to enjoy an immunity against taxation at more than one place similar to that accorded to tangibles." Farmers Loan \& Trust Co. v. Minnesota, stpra at 212. In so doing, he found it convenient to ignore the facts (1) that the constitutional basis upon which the Court had earlier restricted multiple taxation of tangibles [the impossibility of physical location in more than one state at a time; Union Refrigerator Transit Co. v. Kentucky, 199 U. S. 194 (1905)] has no applicability to intangibles, and (2) that the Supreme Court, in establishing the single tax rule for tangibles, had expressly recognized an "obvious distinction" between tangible and intangible property (Union Refrigerator Transit Co. v. Kentucky, supra at 205) which warranted the double standard for which Mr. Justice McReynolds could find "no sufficient reason." The demise of Blackstone v. Miller evoked some of Holmeg" most outspoken dissents. See, for example, Baldwin v. Missouri, 281 U. S. 586, 595 (1930): "I have not yet adequately expressed the more than anxiety that I feel at the ever increasing scope given to the Fourteenth Amendment in cutting down what $I$ believe to be the constitutional rights of the States. As the decisions now stand, I see hardly any limit but the sky to the invalidating of those rights if they happen to strike a majority of this Court as for any reason undesirable. I cannot believe that the Amendment was intended to give us carte blanche to embody our economic or moral beliefs in its prohibitions." See also 2 HoLassPollock LetTERs (1941) 267-71.

3. "We find it impossible to say that taxation of intangibles can be reduced in every case to the mere mechanical operation of locating at a single place, and there taxing, every 
as reestablish an old one. For Mr. Justice Holmes had said, years before, that however undesirable multiple taxation of intangibles might be, correction must be sought elsewhere than in the Fourteenth Amendment. ${ }^{4}$ There has been, however, a curious disinclination on the part of both the Court and its observers to examine critically the basis upon which the Fourteenth Amendment continues to shelter out-of-state tangible property from property and death taxes of the state where the owner resides; indeed, reaffirmation of the Amendment's protective force as to tangibles is to be found in the very decision which, denying that protection to intangibles, said:

". . . it is undeniable that the state of domicile is not deprived, by the taxpayer's activities elsewhere, of its constitutional jurisdiction to tax, and consequently that there are many circumstances in which more than one state may have jurisdiction to impose a tax and measure it by some or all of the taxpayer's intangibles." 3

It is the thesis of this article that the Fourteenth Amendment affords no valid basis for denying to the domiciliary state a correspondingly broad power to tax a resident's tangibles, without regard to their location. ${ }^{6}$

The principal focus of what follows is this constitutional issue, although something will be said, in conclusion, of the social desirability of taxing out-of-state tangibles. By way of anticipation, it may be

legal interest growing out of all the complex legal relationships which may be entered into between persons. . . . The Fourteenth Amendment cannot be carried out with such mechanical nicety without infringing powers which we think have not yet been withdrawn from the states." Curry v. McCanless, 307 U. S. 357, 373 (1939). See also State Tax Commission of Utah v. Aldrich, 316 U. S. 174 (1942), overruling First Nat. Banls v. Maine, 284 U. S. 312 (1932) and reinstating the doctrine of Blackstone v. Miller, 18S U. S. 189 (1903), cited supra note 2.

4. "It seems to me that the result reached by the court probably is a desirable one, but I hardly understand how it can be deduced from the Fourteenth Amendment. . . ." Union Refrigerator Transit Co. v. Kentucky, 199 U. S. 194, 211 (1905). See also Blaclsstone v. Miller, 188 U. S. 189, 201-5 (1903).

5. Curry v. MicCanless, 307 U. S. 357, 368 (1939), cited supra note 3. In this case Mr. Justice Stone says of the doctrine that tangibles are tasable only by the state where located that "its survival and the consequent cleavage between the rules of law applicable to tangibles and those relating to intangibles are attributable to the exclusive dominion exerted over the tangibles themselves by the government within whose territorial limits they are found." Id. at 364. But see Mr. Justice Jackson's speculation in his discent in State Tax Commission of Utah v. Aldrich, 316 U. S. 174, 201 (1942): ". . . since the Due Process Clause speaks with no more clarity as to tangible than as to intangible property, the question is opened whether our decisions as to taxation of tangible property are not due to be overhauled." See also (1940) 54 HaRv. L. Rev. 151, 152, suggesting "a re-examination of the possibility of double taxation of tangible personal property." And sce (1940) 40 CoL. L. REv. 725, 731: "The distinction between tangibles and intangibles is a suparficial one for $\operatorname{tax}$ purposes. ..."

6. See note 115 infra. 
noted that, since state death taxes are graduated according to the decedent's wealth, there seems to be no reason of social policy why out-of-state land, art objects or other tangibles should be excluded from the taxable estate when mortgages on out-of-state/and and deposits in out-of-state banks are included. Different issues of policy are posed by the ad valorem property tax, which almost universally has become a localized levy on real estate quite unrelated to net wealth, because assessment machinery is not geared to include property outside the local district and is not likely to be retooled for that purpose; in those states where the property tax is still employed as a levy upon total wealth, however, the inclusion of out-of-state tangibles could substantially expand the taxable base. In any case, tax practice should be governed by local policy preferences rather than coerced by a constitutional doctrine which has never been subjected to careful analysis.

\section{I}

The immunity of land located in State A from both ad valorem and death taxation by State B, the domicile of its owner, has long been considered so self-evident that judicial dignity precludes discussion of its basis in legal principle or social policy. ${ }^{7}$ But chattels did not

7. "Indeed, we know of no case where a legislature has assumed to impose a tax upon land within the jurisdiction of another State, much less where such action has been defended by any court. It is said by this court in the Foreign-held Bond case, 15 Wall. 300, 319 (U. S. 1873), that no adjudication should be necessary to establish so obvious a proposition as that property lying beyond the jurisdiction of a State is not a subject upon which her taxing power can be legitimately exercised." Union Refrigerator Transit Co. v. Kentucky, 199 U. S. 194, 204 (1905). The second sentence is, of course, question-begging, and furnishes no guide by which one can decide whether "property" is "beyond the jurisdiction of at State" if the person who possesses some or all of the rights to deal with or dispose of it is within the State. Yet such feeble substitutes for reasons are common. See Louisville \& Jeffersonville Ferry Co. v. Kentucky, 188 U. S. 385, 396 (1903) where the Court said that the power to tax "is limited by a principle inhering in the very nature of constitutional Government, namely, that the taxation imposed must have relation to a subject within the jurisdiction of the taxing Government." These and similar platitudes no doubt derive from the resounding pronouncement of Chief Justice Marshall, in McCulloch v. Maryland, 4 Wheat. 316,429 (U. S. 1819): "All subjects over which the sovereign power of a stato extends, are objects of taxation; but those over which it does not extend, are, upon the soundest principles, exempt from taxation." Compare Mr. Justice Jackson dissenting, in State Tax Commission of Utah v. Aldrich, 316 U. S. 174, 201 (1942): "I find little difficulty in concluding that exaction of a tax by a State which has no jurisdiction or lawful authority to impose it is a taking of property without due process of law. The difficulty is that the concept of jurisdiction is not defined by the Constitution." The due process clause of the Fifth Amendment does not encumber the federal taxing power with the restrictions imposed upon the states by the corresponding clause of the Fourteenth Amendment. Burnet v. Brooks, 288 U. S. 378 (1933); 1 PAul, Federal Estate and Gift Taxation (1942) $\S \S 2.08-$ 10; Wurzel, Foreign Invesiment and Extraterritorial Taxation (1938) 38 CoL. L. REv. 809; Notes (1937) 46 Yale L. J. 687; (1937) 37 Col. L. Rev. 500. Paul, ibid., states that "any lingering doubts" as to the power of the United States to tax foreign real estate should be 
gain a parallel immunity from property taxation until the dawn of the twentieth century, and did not win freedom from multiple death taxes for another quarter-century. ${ }^{8}$ As late as 1886, Mr. Justice Bradley regarded with equanimity the possibility that the state of domicile might tax a resident's tangible personalty, wherever located, on the theory that it was "part of his general estate attached to his person," and held that it was "hardly necessary to cite authorities on a point so elementary" as that the state where the chattels were kept might also impose a property tax.9 During the nineteenth century "no restrictions were placed upon the power of the State to levry a tax measured by all the movable property, wherever situate, of any persons domiciled within that State." 10

It was not until 1905 that the Supreme Court first clearly conferred on chattels the same immunity from multiple taxation that had long been enjoyed by land. When Kentucky sought to tax a local corporation on a fleet of migratory railroad cars used almost entirely outside the state, the Supreme Court held, in Union Refrigerator Transit Company v. Kentucky, ${ }^{11}$ that since Kentucky rendered no protection or other "benefit" to the cars, imposition of the tax was in violation of the due process clause of the Fourteenth Amendment. ${ }^{12}$ While this view was not entirely without harbingers, ${ }^{13}$ it was the first to supply ideological ammunition to the campaign against double taxation:

removed by Cook v. Tait, 265 U. S. 47 (1924), upholding a federal income tax upon a nonresident citizen's income from real estate located abroad. In New York ex rel. Cohn v. Graves, 300 U. S. 308 (1937), the Court upheld the power of a state to tax a resident's income from real property located outside its territorial limits, but only on the theory that "the incidence of a tax on income differs from that of a tax on property."

8. Courts did, however, show a marked tendency to construe statutes as not intended to include extra-territorial chattels, particularly by refusing to apply the maxim mobilia sequantur personam when the statute embraced only property "within the state," Hoyt v. Commissioners, 23 N. Y. 224 (1861), Connell v. Crosby, 210 Ill. 380,71 N. E. 350 (1904), or by declining to permit double taxation in the absence of irrefutable evidence that the legislature intended it. But the power of the legislature was admitted: "That the legislature has power to impose a tax on residents upon the personal property owned by them, no matter where the same is situated, is conceded." Weaver's Estate v. Yowa, 110 Iowa 328, 330, 81 N. W. 603 (1900); see Mlagll and MLaguire, Cases on tae LaW of Tasitios: (3d ed. 1940) 313-4. But of. Matter of Estate of Swift, 137 N. Y. 77, 84, 32 N. E. 1096, 1097 (1893).

9. Coe v. Errol, 116 U. S. 517, 524 (1886).

10. Harding, Double Taxation of Property and Incosse (1933) 10.

11. 199 U. S. 194 (1905). ". . . this decision, by reason of its full and lucid exposition of the concept of due process as a basic requirement of taxing jurisdiction, rightly deserves to be ranked the leading case upon the subject." Merrill, Jarisdiction to Tax-Another Word (1935) 44 YALE L. J. 582, 584-5.

12. If the Union Refrigerator Transit Company had been taxed only on a proportionate or "average" basis, the assessment would have included annually between 28 and 67 of its 2000 cars. 199 U. S. 194, 195-6 (1905).

13. See Louisville \& Jeffersonville Ferry Co. v. Kentucly, 188 U. S. 385 (1903); Dela- 
"The power of taxation, indispensable to the existence of every civilized government, is exercised upon the assumption of an equivalent rendered to the taxpayer in the protection of his person and property, in adding to the value of such property, or in the creation and maintenance of public conveniences in which he shares, such, for instance, as roads, bridges, sidewalks, pavements, and schools for the education of his children. If the taxing power be in no position to render these services, or otherwise to benefit the person or property taxed, and such property be wholly within the taxing power of another State, to which it may be said to owe an allegiance and to which it looks for protection, the taxation of such property within the domicil of the owner partakes rather of the nature of an extortion than a tax, and has been repeatedly held by this court to be beyond the power of the legislature and a taking of property without due process of law." 14

A second ground of the Union Refrigerator Transit decision, which is hardly more than a restatement of the first, was that the fleet of cars was beyond the "territorial jurisdiction" of Kentucky:

"It is also essential to the validity of a tax that the property shall be within the territorial jurisdiction of the taxing power. Not only is the operation of state laws limited to persons and property within the boundaries of the State, but property which is wholly and exclusively within the jurisdiction of another State, receives none of the protection for which the tax is supposed to be the compensation." 15

This "reason," like the first, rests upon the unarticulated assumption, which will be analyzed further below, that the "protection" for which the tax is the quid pro quo must be furnished to the physical objects by which the tax is measured rather than to the owner or to the owner's bundle of rights, powers, and privileges with respect to the physical objects. The Court moves from this assumption, by way of the weasel phrase "territorial jurisdiction," 16 to a foregone conclusion.

The court's alchemy not only transmuted into constitutional dogma the "benefit" theory of taxation, which even then enjoyed something less than universal loyalty from economists, ${ }^{17}$ but imposed the addi-

ware L. \& W. R. R. v. Pennsylvania, 198 U. S. 341,355 (1905); cf. Commonwealth v. American Dredging Co., $122 \mathrm{~Pa}$. 386, 390-1, 15 Atl. 443, 444 (1888). For earlier cases resting on general theories of jurisdiction rather than on the Fourteenth Amendment, sce Goodnow, Congressional Regulation of State Taxation (1913) 28 PoL. Scr. Q. 405, 408-13.

14. 199 U. S. 194, 202 (1905).

15. Id. at 204 (1905).

16. See note 7 supra.

17. Mili, Princtples of Political Economy, Bk. V, c. II, $\S 2$; $c$. Seligman, Essays IN TAXation (1921) 333-8 (originally published in 1908); SMITH, ThE WEaldit of NAtions, Bk. V, c. II, Part 2; Schultz, American Public Finance (1942) 283-5; Wells, Tuz Theory and Practice of Taxation (1900) 222-3. 
tional restriction that the "benefit" conferred by the state would not support a tax, at least if it is called a "property" tax, unless somehow related to the property as well as to its owner. Yet this restriction, for some unexplained reason, is apparently applicable only if the "property be wholly within the taxing power of another state;" at least these words have furnished the escape route by which the Court has upheld the taxability of a resident's property when, notwithstanding its permanent location outside the taxing state, it would otherwise go tax free. The classic instance is Southern Pacific Company' v. Kentucky, ${ }^{18}$ which sustained a tax levied by Kentucky on a fleet of steamships owned by a local corporation but permanently employed on the high seas. Yet if the due process clause is violated by a tax on railroad cars which receive no police or comparable protection from Kentucky, how can an exception be found in the Fourteenth Amendment to support the taxation of the Southern Pacific Company's ocean-going steamships? The fact that these vessels receive no taxable "protection" from their ports of enrollment or call in no way increases the "protection" afforded to them by Kentucky. Nor can any reason of social policy be found in these circumstances for conditioning taxability at home on immunity elsewhere. If the Southern Pacific Company can be required to contribute, in proportion to its total wealth, to the support of the state from which it has received its corporate charter, why should not the Union Refrigerator Transit Company do likewise, even though the latter-because of additional benefits received from another state-may also be paying a tax there?

If the territorial limit on taxation which -the Court found in the Fourteenth Amendment is not consistently observed with respect to tangible property, it is ignored -as it must be-when intangibles are the subject of taxation. For when the state requires its citizens to include the value of money owed to them in reporting their taxable wealth, even the impressive maxim mobilia sequuntur personam cannot conceal for long the fact that the "property" being taxed is neither within nor without the state's territorial limits. A debt has no physical location, even though the debtor and creditor have, nor does it receive the kind of physical protection from the police and fire departments that allegedly is the exclusive basis for taxing land, railroad cars, or other tangible property. ${ }^{19}$ Nonetheless, a person to whom money was owing-far from being relieved of all taxation because of the spiritual nature of his property-could be taxed, at the time the Union Refrig-

18. 222 U. S. 63 (1911).

19. With respect to intangible property, "jurisdiction has not been thought to depend on any factor other than the domicile of the owner within the taxing state, or to compal the attribution to intangibles of a physical presence within its territory, as though they viere chattels, in order to support the tax." Mr. Justice Stone, in Curry v. MicCanless, 307 U.S $357,366-7$ (1939). 
erator Transit case was decided, by both the debtor's state and his own. ${ }^{20}$

Recognizing that an immunity was being conferred upon chattels which was not then enjoyed by intangibles, the Court in Union Refrigerator Transit Co. v. Kentucky found an "obvious distinction" between tangible and intangible property, in that the latter is "held secretly" so "that there is no method by which its existence or ownership can be ascertained in the State of its situs, except perhaps in the case of mortgages or shares of stock." The Court also asserted that even if the non-resident owner is known, there is no way of collecting the tax except in the state of his domicile.

The fact that intangible property is "held secretly" was thought to warrant its treatment as fair game by the tax assessors of both the creditor and debtor states, double taxation being constitutionally unexceptionable because "it much oftener happens that this class of property escapes altogether." The sins of some mortgagees were visited upon others, as it were; one had to pay double to compensate for the evasions of another. ${ }^{21}$ In relieving the owners of tangibles of such vicarious liability, the Court asserted but made no effort to prove that tangibles cannot be as easily hidden from the tax collector as intangibles. But the accuracy of this assumption is far from obvious. The domiciliary state must depend upon the taxpayer's honesty for disclosure of his out-of-state property, whether in the tangible form of real estate, railroad cars, and precious metals, or in the intangible form of mortgages, bank deposits, trust funds, or securities. The nondomiciliary state, of course, can find the non-resident's real property by examining the land records in the county clerk's office, but it also can find his mortgages recorded there. Bank deposits, trust funds, securities, and unsecured loans no doubt are more difficult to track down, but local debtors, fiduciaries, and corporations could be required to file information returns, or disclosure could be made a condition to

20. In Kirtland v. Hotchkiss, 100 U. S. 491 (1879), the Court had upheld the power of the creditor's state to impose an ad valorem property tax: "The debt is property in his hands constituting a portion of his wealth, from which he is under the highest obligation, in common with his fellow-citizens of the same State, to contribute for the support of the government whose protection he enjoys." Id. at 498 . For the validity of a similar tax by the debtor's state, at least when the debt was evidenced by a bond, note or mortgage, see Savings and Loan Society v. Multnomah County, 169 U. S. 421 (1898) and New Orleans v. Stempel, 175 U. S. 309 (1899). Both the creditor's and the debtor's state had jurisdiction for death tax purposes, Blackstone v. Miller, 188 U. S. 189 (1903). For the vicissitudes of this doctrine, see notes 2 and 3 supra.

21. As Powell has pointed out in another connection: "It is of course a matter of chance whether the owners who are caught are the same as those who have escaped. Only when they are, can the property taxed be regarded as representative of what had previously passed by unscathed." Comment, Northwest Airlines v. Minnesola: State Taxation of Airplanes-Herein Also of Ships and Sealing Wax and Railroad Cars (1944) 57 Harv. L. REv. $1097,1098$. 
local enforcement of the obligations by the non-resident. ${ }^{22}$ While devices of this type are far from perfect, there is no reason to suppose that they are not at least as effective as any measures which can be devised to search out movable tangibles, like railroad cars, works of art, precious metals, and the like, which a non-resident may choose to use or conceal within the jurisdiction. To the extent that the constitutional distinction between tangibles and intangibles must rest on the greater ease with which the former can be found by the tax collector, it is on flimsy underpinnings indeed.

Nor does the other branch of the not so "obvious distinction" between tangibles and intangibles-that it is impossible to collect the tax from the non-resident owner of intangibles-appear provable, even if it could otherwise be thought to furnish an adequate basis for constitutional differences. It is entirely possible that we are on the threshhold of a breakdown of the doctrine, sanctified by nothing beyond age, that one state will not enforce the tax laws of another. ${ }^{23}$ Even without such an addition to the tax collector's arsenal, however, more than one techrique is presently available for collecting a tax from a non-resident owrer of intangible property. The most obvious would be garnishment of the non-resident's bank deposits, loans, and other credits in a fashion comparable to the assertion of a tax lien on real property. Restraints on the transfer of corporate stocks and bonds until nonresident owners thereof have paid all personal property taxes would be another effective device. Similarly, enforcement in the taxing state's courts of debts or other obligations might be prohibited whenever the taxes thereon are delinquent. ${ }^{24}$ So far as death taxation is concerned, the intangible property of a non-resident decedent is easily reached by virtue of familiar statutory provisions forbidding the transfer of property except with the consent of the state taxing officers. ${ }^{25}$ These devices for collection differ in detail from, but are not necessarily less effective than, the lien and foreclosure method which must be used for collecting taxes due in respect of the non-resident's tangible property. The assumption that intangibles are more likely than tangibles to go entirely

22. See, for example, Markwell v. Kahlkoff, $258 \mathrm{Ky} .231,79 \mathrm{~S}$. W. (2d) 984 (1935); McLaughlin v. Cheney, 172 Okla. 562, 46 P. (2d) 352 (1935); Poss v. Albert, 139 Tenn. 1, 200 S. W. 976 (1918). See further Leland, The Classinied Property Tax in me United States (1928) 145-6.

23. State ex rel. Oklahoma Tax Commission v. Rodgers, - Mo. App. 193 S. W. (2d) 919 (1946); see Note (1946) 165 A. L. R. 796. Leflar, Ex/raslate Enforcenenl of Penal and Goternmental Claims (1932) 46 HARv. L. REv. 193; Freeze, Extraterritorial Erforcement of Rerenue Laws (1938) 23 WasH. U. L. Q. 32; Daum, Interslale Conily and Gorernmental Claims (1938) 38 IlL. L. Rev. 249; Comment (1935) 48 H.rsv. L. Rev. 828.

24. See note 22 supra.

25. The C. C. H. State Inheritance, Estate, and Gift Tax Service sets out, with statutory references, the requirements of each state as to consents by the local taxing authority to the transfer of a decedent's assets. See paragraph 2300 ff. for each state. 
unscathed by taxation unless more than one state has authority over them cannot survive analysis; yet this false assumption forms the very foundation of the "obvious distinction" between tangibles and intangibles which has been thought to support taxation of the latter at the owner's home as well as elsewhere while denying parallel taxability of the former.

Nevertheless, this differentiation persisted for many years without significant alteration as the justification for the double standard in the Fourteenth Amendment's behavior toward the taxpayer. But when the Supreme Court at its 1929 Term opened its campaign against multiple taxation of intangibles, ${ }^{26}$ the "obvious distinction" quite naturally fell into desuetude. In Farmers Loan \& Trust Co. v. Minne$s o t a,{ }^{27}$ the Court held that the power to tax the testamentary transfer of state and municipal bonds (and, by implication, other choses in action) lies exclusively with the state of the creditor's domicile. Now the Court, though not losing sight of the "obvious distinction," sought to assimilate the treatment of intangibles with that of tangibles:
"We have determined that in general intangibles may be properly taxed at the domicile of their owner and we can find no sufficient reason for saying that they are not entitled to enjoy an immunity against taxation at more than one place similar to that accorded to tangibles. The difference between the two things, though obvious enough, seems insufficient to justify the harsh and oppressive dis- crimination against intangibles contended for on behalf of Minne- sota." 28

The war on double taxation lasted long enough to stimulate a host of comments and at least two books ${ }^{29}$ and to cripple a growing movement for statutory adjustment of the conflicting claims of the several states. ${ }^{30}$ Then the Court abandoned the struggle as to intangibles.

26. An early foreshadowing of the 1929-1930 campaign is to be found in State Tax on Foreign Held Bonds, 15 Wall. 300 (U. S. 1873), "perhaps the most misunderstood, mis-cited, and abused case in the law relating to taxation." Harding, Double TAxation of PropERTY AND INCOME (1933) 29. This case has been all things to all men. See the summary of the variegated "explanations" of its meaning in HARDING, $i b i d$.

27. 280 U. S. 204 (1930).

28. Id. at 212 .

29. Harding, Double Taxation of Property and Inconse (1933), reviewed by Magill (1934) 34 CoL. L. REv. 794, and by Rottschaefer (1934) 82 U. of PA. L. REv. 670; Stimson, Jurisdiction and Power of Taxation (1933), reviewed in (1934) 47 Harv. L. REv. 1466.

30. At the time First Nat. Bank v. Maine, 284 U. S. 312 (1932) was argued, thirtyseven states had enacted reciprocity statutes exempting from death taxes the local intangible property of decedents domiciled in states which bestowed a similar immunity on their own citizens. State Tax Commission of Utah v. Aldrich, 316 U. S. 174, 197 (1942). See also Brady, Death Taxes-Recent Statutory and Judicial Solutions of Mulliple Taxation (1930) 16 A. B. A. J. 532; Faught, Reciprocity in State Taxation as the Next Step in Empirical 
But there was no retreat from its single tax doctrine for tangibles; in Curry v. MicCanless, ${ }^{31}$ the most unequivocal though not strictly the first ${ }^{32}$ announcement that the war was over, Mr. Justice Stone revived the double standard, borrowing from his dissenting opinion in an earlier case ${ }^{33}$ a long passage to refurbish the old "obvious distinction" with a more elaborate analysis:

"That rights in tangibles-land and chattels-are to be regarded in many respects as localized at the place where the tangible itself is located for purposes of the jurisdiction of a court to make disposition of putative rights in them, for purposes of conflict of laws, and for purposes of taxation, is a doctrine generally accepted both in the common law and other legal systems before the adoption of the Fourteenth Amendment and since. Originating, it has been thought, in the tendency of the mind to identify rights with their physical subjects, see Salmond, Jurisprudence (2nd ed.) 398, its survival and the consequent cleavage between the rules of law applicable to tangibles and those relating to intangibles are attributable to the exclusive dominion exerted over the tangibles themselves by the government within whose territorial limits they are found. ... The power of government and its agencies to possess and to exclude others from possessing tangibles, and thus to exclude them from enjoying rights in tangibles located within its territory, affords adequate basis for an exclusive taxing jurisdiction. When we speak of the jurisdiction to tax land or chattels as being exclusively in the state where they are physically located, we mean no more than that the benefit and protection of laws enabling the owner to enjoy the fruits of his ownership and the power to reach effectively the interests protected, for the purpose of subjecting them to payment of a tax, are so narrowly restricted to the state in whose territory the physical property is located as to set practical limits to taxation by others. Other states have been said to be without jurisdiction and so without constitutional power to tax tangibles if, because of their location elsewhere, those states can afford no substantial protection to the rights taxed and cannot effectively lay hold of any interest in the property in order to compel payment of the tax." 34

In its twin emphasis upon the protection afforded to tangible property by the state of its location and upon the ease with which a tax may be

Legislation (1944) 92 U. of PA. L. REv. 258; Comment, Reciprocal and Retaliatory Tax Statules (1930) 43 Hanv. L. Rev. 641; Comment (1940) 26 Iowa L. Rev. 694; of. Sen. Doc. No. 69 (Federal, State, and Local Government Fiscal Relations) 78th Cong., 1st Ses. (1943) 490-6.

31. 307 U. S. 357 (1939).

32. See 307 U. S. 357, 363 n. 1; of. Schuylkill Trust Co. v. Pennsylvania, 302 U.S. 506

(1938); First Bank Stock Corp. v. Minnesota, 301 U. S. 234 (1937).

33. Senior v. Braden, 295 U. S. 422 (1935).

34. 307 U. S. 357, 363-1 (1939). 
collected there, Mr. Justice Stone's rationale invites the same criticism as did the Union Refrigerator Transit Company case: if the owner of deposits in out-of-state banks or of mortgages on out-of-state land may be taxed because he enjoys the privileges of residence, citizenship, incorporation, or the like in the state of his domicile, why is not the enjoyment of similar privileges by the owner of out-of-state land or railroad cars a sufficient basis for taxing him? ${ }^{35}$ Indeed, if the Supreme Court were consistently to deny taxing jurisdiction to "those states that can afford no substantial protection to the rights taxed and cannot effectively lay hold of any interest in the property in order to compel payment of the tax," ${ }^{36}$ it could not accommodate a case like Southern Pacific Co. v. Kentucky. ${ }^{37}$ In fact, no out-of-state property, whether tangible or intangible, would meet the test, unless the "rights taxed" which must be "protected" are the various rights which make up ownership, in which case the way would be equally open to taxation on both classes of property.

This suggestion leads us to an appraisal of Mr. Justice Stone's analysis of the basis upon which jurisdiction to tax intangibles rests: viz., that intangibles, being legally enforceable "relationships between persons," "cannot be dissociated from the persons from whose relationships they are derived" and may be taxed by the state in which those persons enjoy the benefits of government. ${ }^{38}$ This realistic analysis of intangible property affords a more secure foundation for "jurisdiction" to tax intangibles than the stilted and rarefied language of "situs," 30 but in burning away the tangled underbrush Mr. Justice Stone, unwittingly perhaps, set fire to the trees as well. For any post-Hohfeldian lawyer will ask almost instinctively if "tangible property" is not also composed of legally enforceable relationships between persons, or if tangibles any more than intangibles can be "dissociated"- "as sources of actual or potential wealth"- "from the persons from whose relationships they are derived." The owner of a plot of land or of a railroad car ("tangibles") is just as much dependent as the owner of a share of corporate stock or of a promissory note ("intangibles") upon judicial assistance in requiring other persons to act or refrain from acting in various ways. The fact that the landowner's rights are often, with perhaps pardonable hyperbole, denominated rights against "all the

35. Compare Holmes, dissenting, in Safe Deposit and Trust Co. v. Virginia, 280 U. S. 83, 97 (1929): "Taxes generally are imposed upon persons, for the general advantages of living within the jurisdiction, not upon property. . . . The notion that the property must be within the jurisdiction puts the emphasis on the wrong thing."

36. Curry v. McCanless, 307 U. S. 357, 364 (1939).

37. 222 U. S. 63 (1911), cited with approval by Mr. Justice Stone in his dissenting opinion in Northwest Airlines v. Minnesota, 322 U. S. 292, 309, 312, 314 n. 2 (1944).

38. Curry v. McCanless, 307 U. S. 357, 366 (1939).

39. See Farmers Loan \& Trust Co. v. Minnesota, 280 U. S. 204 (1930). 
world" should not obscure a recognition that, in protecting his rights, the courts are concerning themselves with "relationships between persons" (between the owner, his agents, assignees, heirs, etc. and his neighbors, visitors, trespassers, etc.) and that any "control of a physical thing" is exerted chiefly by judicial orders directed to persons. Applying this analysis, which is so fully developed in the writings of Hohfeld and Cook, ${ }^{40}$ one could easily paraphrase MIr. Justice Stone:

"[Rights to land, railroad cars, and art objects] are but relationships between persons, natural or corporate, which the law recognizes by attaching to them certain sanctions enforceable in courts. ... They can be made effective only through control over and protection afforded to those persons whose relationships are the origin of the rights. . . . Obviously, as sources of actual or potential wealth-which is an appropriate measure of any tax imposed on ownership or its exercise-they cannot be dissociated from the persons from whose relationships they are derived."

Justice Stone's failure to accept the full consequences of his own analysis reflects the quaint notion, sanctified by usage, that an ad valorem tax is laid "on" the property taved "L-meaning, in the case of land or railroad cars, "on" the physical object itself. He suggested that the localization, for judicial purposes, of rights in land and chattels at the place where the physical object is located may have originated "in the tendency of the mind to identify rights with their physical subjects" 42 and argued that the survival of this view and the consequent cleavage in legal treatment of tangibles and intangibles "are attributable to the exclusive dominion exerted over the tangibles themselves by the government within whose territorial limits they are found." We are not told why the identification of rights with physical objects which has led to so much confusion ${ }^{43}$ should be perpetuated nor whether it can find any support in terms of current social needs.

40. Hohfeld, Fundamental Legal Conceptions (1923) 28-30, 73-95; Coos, The Logical aNd Legal Bases of the Conflict of Laws (1942) 28t-300; Cools, Rescission of Bargains Made on Sunday (1935) 13 N. C. L. Rev. 165, 173-9; Comment (1926) 35 YALE L. J. 357. Note Holmes: "All rights are intangible personal relations between the subject and object of them created by law." Citizens Nat. Banls v. Durr, 257 U. S. 99, 110 (1921).

41. See Rodell, A Primer on Interslate Taxalion (1935) 44 YaLE L. J. 1166; cf. note 35 supra.

42. Curry v. MeCanless, 307 U. S. 357, 364 (1939).

43. Compare Holmes: "The fact that tangible property is also visible tends to give a rigidity to our conception of our rights in it that we do not attach to others less concretely clothed." Block v. Hirsh, 256 U. S. 135, 155 (1921). The very passage cited by Stone to support his historical explanation says that the confusion of rights with physical objects has given rise to an "unfortunate attempt" to classify rights (as well as objeets) as either "moveable" or "immoveable." According to S.LMoND, JuRISPRudence (9th ed. 1937) §155:

"It is clear that the distinction between movables and immovables is in truth 
While Mr. Justice Stone did not address himself to the desirability of perpetuating the confusion between rights and objects, he came very close to giving us an answer. He said, for example, that taxation "is but a means of distributing the cost of government among those who are subject to its control and who enjoy the protection of its laws" and that wealth "is an appropriate measure of any tax imposed on ownership or its exercise." 44 If so, why should a discredited tendency to confuse rights with objects serve to deny to a state the power to require one who is subject to its control and who enjoys the protection of its laws to contribute to its support in proportion to his wealth wherever, and in whatever form, it may be invested? Some states may choose to exempt some or all wealth invested in another jurisdiction, either by including only local investments in the definition of taxable wealth or by allowing an offset of out-of-state levies against local taxes. But these are-or should be-matters of local social policy rather than inflexible doctrines of constitutional law.

While in the field of ad valorem taxation the confusion of rights with objects finds some explanation-if not an excuse-in the traditional view that the tax is "on" the object taxed rather than "on" the owner or his wealth, there is not even this reason for confusing the two in the case of death taxes. Even the orthodox view is that such taxes are

and in fact applicable to material objects only. Yet the law has made an unfortunate attempt to apply it to rights also. Rights no less than things are conceived by the law as having a local situation, and as being either movable or permanently fixed in a definite locality. The origin of this illogical conception is to be found in the identification of rights of ownership with the material things which are the objects of them. I am said to own land and chattels, as well as easements, shares, debts, contracts, and patents. All these things are equally property, and since some of them have a local situation and can be truly classed as movable or immovable, the law has been led by inadvertence to attribute these qualities to all of them. It has recognised in things which are incorporeal certain attributes which in truth pertain to things corporeal only. It has divided the whole sphere of proprietary rights by reference to a distinction which is truly applicable not to rights at all, but to physical objects."

On this theory, debts have their situs "where the debtor resides, since it is there that the creditor must go to get his money." The conceptualistic thinking that Salmond engages in cannot be appreciated without reading his work, and it is little short of astounding that Stone should take seriously what even Salmond recognized as an "illogical conception." It is especially surprising since only a page or two earlier in the same opinion Stone had pointed to the impossibility "of attributing a single location to that which has no physical characteristics." 307 U. S. 357, 362-3 (1939). And on an earlier occasion Stone had written: "The Fourteenth Amendment did not adopt as ultimate verities the quaint distinctions taken three centuries ago by Sir Edward Coke between things that savour of the realty and other forms of right, and between corporeal and incorporeal rights. In applying the Fourteenth Amendment we may recognize, what he failed to realize, that all rights are incorporeal. . . ." Senior v. Braden, 295 U. S. 422, 438 (1935). See also HoHFELd, loc. cil. supra note 40.

44. Curry v. McCanless, 307 U. S. 357, 370, 366 (1939). 
levied "on" the privilege of transfer, or of succession, rather than on the property. ${ }^{45}$ Moreover, since only rightis can be transferred at death or inherited, ${ }^{46}$ a tax measured by the value of the decedent's entire estate could be upheld on the ground that the property transferred (i.e., rights, i.e., "relationships between persons") is within the taxing jurisdiction of the state where the decedent lived because it has control over at least one of the parties (the decedent's executor) to the relationship which is being altered. Any argument based on the domiciliary state's lack of power to prescribe the succession to tangibles located elsewhere, unless the state of situs concurs, runs afoul of the fact that it similarly lacks power to govern the testamentary transfer of a chose in action or of a share of stock if the state where the obligor, debtor or corporation is located prescribes a different succession.

\section{III}

It should occasion no surprise that the courts have floundered hopelessly in applying a distinction which stands on such an uncertain legal foundation and is so singularly deficient in economic significance as that between tangible and intangible property. Differences of degree we must expect in the law, and the judicial task is above all the drawing of lines; ${ }^{47}$ but where the extremes themselves do not differ significantly from each other, any boundary line between them is peculiarly unacceptable. Even a cursory survey will uncover a number of conceptual frontiers which, born of judicial desperation, can hardly be expected to survive for long.

Interests in land. A convenient starting point is Senior v. Braden, 49 holding Ohio powerless to impose its personal property tax on certain land trust certificates evidencing a resident taxpayer's beneficial interest in parcels of real estate, located without the state, the legal titles to which were held under declarations of trust by trustees. Each declaration of trust required the trustee to hold and manage the property for the benefit of the certificate owners and to distribute the income or proceeds of sale to them in proportion to their interests. It was conceded by the state, with "commendable frankness," according

45. Fernandez v. Wiener, 326 U. S. 340, 352-3 (1945); United States Trust Co. v. Helvering, 307 U.S. 57 (1939); Knowlton v. Moore, 178 U.S. 41 (1900). While characterization of the federal estate tax as being "on" the privilege of transfer rather than "on" the transferred property has been motivated by the constitutional distinction between direet and indirect taxes, state death taxes have been similarly characterized. See Stebbins and Hurley v. Riley, 268 U.S. 137 (1925); Buck v. Beach, 206 U. S. 392, 408 (1907).

46. See Restateasent, Property (1936) §\$12-3.

47. See United States v. Antonelli Fireworks Co., 155 F. (2d) 631,647 n. 15 (C. C. A. 2d, 1946).

48. 295 U. S. 422 (1935). A forerunner of Senior v. Braden is Narragansett Mut. Fire Ins. Co. v. Burnham, 51 R. I. 371, 154 Atl. 909 (1931). 
to the Court, that if the tax were being assessed against "land or interests in land," it would be unconstitutional. ${ }^{49}$ The Court held that the taxpayer owned not a bundle of equitable choses in action, taxable as intangible property, but rather interests in the lands which constitute the corpora of the trusts. Mr. Justice Stone, with whom Justices Brandeis and Cardozo joined, dissented. ${ }^{50}$

It is plain folly to have airy distinctions like that between "equitable chose in action" and "interest in land" control the citizen's duty to contribute to the support of his government in proportion to his means. If $\mathrm{Mr}$. Senior had invested his money in the shares of a real estate investment corporation ${ }^{51}$ or in mortgage participation certificates ${ }^{62}$ rather than in fractional trust certificates, he would have been liable for the claimed tax, notwithstanding the absence of any substantial economic differences in his investment position. The manipulation of legal concepts, solely to create "a tax-free form of investment," "43 has not obscured recognition by other courts that Ohio land trust certificates are used "in financing real estate loans as a substitute for an outright mortgage," ${ }^{54}$ nor has it prevented the owners of such certificates from obtaining federal income tax benefits on a plea that the instruments, though creating a trust on their face, are in reality only a mortgage. ${ }^{55}$ The Supreme Court, failing to take judicial notice of what

49. This concession was thought to be compelled by the due process clause of the Fourteenth Amendment. 295 U. S. 422, 426. The concession was also made with respect to similar certificates evidencing the ownership of real estate located within the state, because Art. XII, $\S 2$ of the Ohio Constitution permits taxation of land and improvements only by "uniform rule according to value," while the questioned tax statute, OHro SEN. CoDE ANN. (Page, 1937) §§ 5388-9, imposed upon "productive investments" a tax measured by income yield while taxing "unproductive investments" according to "the true value thereof."

50. For a sprightly dissection of the Court's opinion, see Rodell, WoE UNro You, LAwYers! (1939) 103-34. For analogous problems, see Waggoner Estate v. Wichita County, 273 U.S. 113 (1927); Note (1945) 156 A. L. R. 22, 193-6.

51. Hawley v. Malden, 232 U. S. 1 (1914); of. Curry v. McCanless, 307 U. S. 357, $365 \mathrm{n} .3$ (1939). It is worthy of note, moreover, that the owners of shares of a corporation which does not pay local taxes on its property may constitutionally be taxed more heavily than the owners of shares of a corporation that does. Klein v. Board of Tax Supervisors, 282 U. S. 19 (1930).

52. See. Curry v. McCanless, 307 U. S. 357,365 n. 3 (1939); Kirtland v. Hotchkiss, 100 U. S. 491 (1879).

53. First Nat. Bank of Cincinnati v. Rawson, 56 Ohio App. 388, 11 N. E. (2d) 110, 112 (1937); Nitkey v. Ward, 199 Minn. 334, 271 N. W. 873 (1937), cert. denied, 302 U. S. 706, 775 (1937); City Nat. Bank Bldg. v. Helvering, 98 F. (2d) 216, 222 (App. D. C. 1938). For more detailed discussion see Goldman and Abbott, Land Trust Certificates (1928) 2 U. of CIN. L. Rev. 255.

54. Cleveland Trust Co. v. Commissioner, 115 F. (2d) 481,482 (C. C. A. 6th, 1940), cert. denied, 312 U. S. 704 (1941).

55. Helvering v. F. \& R. Lazarus \& Co., 308 U. S. 252 (1939); Commissioner v. H. F. Neighbors Realty Co., 81 F. (2d) 173 (C. C. A. 6th, 1936). See also In re Euclid Doan Co., 104 F. (2d) 712 (C. C. A. 6th, 1939), declaring a trust deed to be a mortgage for purpose of bankruptcy administration. 
was "common knowledge" ${ }^{56}$ in Ohio, looked only to the face of the documents, and found that the owner had an interest in land.

Actually, the most significant issue in the case (whether "interests in land" are comparable, tax-wise, to land) was conceded by the state. Yet the reasoning employed in the Union Refrigerator Transil case to confer immunity from taxation upon out-of-state tangible property has no applicability to subordinate or partial interests in such property. For the bedrock of the immunity doctrine is that immune property is protected only by the state where it is physically located, that it is "visible" and thus easily found by the tax collector, and that it is therefore "obviously" different from intangible property. An interest in land, whether it is the interest of a mortgagee, unpaid vendor, equitable owner, beneficiary of a trust, or whatever, has all the characteristics which, according to the court in the Union Refrigerator Transit case, subject intangible property to taxation by the state of the owner's domicile, while it shares none of the characteristics which were thought to confer a parallel immunity on tangible property. The concession of counsel for the state in Senior v. Braden enabled the Court to evade the task of explaining how an immunity possessed by property solely because of its physical characteristics could also be claimed on behalf of interests in that property.

Equitable conversion. The doctrine of "equitable conversion" also serves to illustrate how shadowy is the boundary between tangible and intangible property. The "mysterious statements" 57 found in opinions and treatises that land is "equitably converted" into money immediately upon the making of a contract for its sale have been imported from unrelated fields of the law into the law of taxation. ${ }^{53}$ The original importers were the Pennsylvania courts, which employed the doctrine for the purpose of subjecting to the state inheritance tax the transmission at death of land lying outside the state. The equitable catalyst was employed because the taxing statute did not embrace the transfer of land outside the state; ${ }^{59}$ the exclusion was rendered partially ineffective by judicial holdings that if the testator had by will directed that the land be sold rather than transferred directly, the direction would be regarded as having "worked an equitable conversion" of the

56. See note 53 supra.

57. Cook, The Logical and Legal Bases of the Conflict of Laws (1942) 256.

58. For a survey of the principal fields in which the doctrine of equitable conversion has found application, see Simpson, Legislatize Changes in the Law of Equilable Cortersion by Contract (1935) 44 YaLE L. J. 559, 754; $c f$. Stone, Equilable Conrcrsion by Contract (1913) 13 CoL. L. REv. 369. While recent discussion has centered on conversion by contract, the doctrine is also applied, and indeed is of principal importance taxwise, where there is a testamentary direction to sell rather than an executory contract of sale. See Povsesor, Equiry JURISPRUDENCE (4th ed. 1918) $\$ \$ 161,371,1159-78$; M1AItLa:TD, Eouiti (2d ed. 1936) 277-86. For an early American discussion, see Craig v. Leslic, 3 Wheat. 563 (U. S. 1818).

59. Commonwealth v. Coleman's Administrator, $52 \mathrm{~Pa} .46 \mathrm{~S}$ (1866). 
land so that the value thereof could be subjected, like personalty, to the tax. ${ }^{60}$ The Pennsylvania doctrine was followed by other states, but did not command general acceptance. ${ }^{61}$ As a device for subjecting out of state tangibles to local property taxes, equitable conversion has apparently been employed rarely if ever, notwithstanding its use in allocating the burden of such taxes as between vendor and purchaser of land subject to an executory contract of sale. ${ }^{62}$

For all the confused and confusing conceptual nonsense which it has spawned, the doctrine of equitable conversion may possibly serve useful ends-in other fields than taxation. ${ }^{63}$ It may be, for example, that a testator who by will directs his executors to sell his real estate intends the proceeds of sale to descend to his legatees rather than to his devisees. If so, the doctrine of equitable conversion is a harmless rationalization to promote the decedent's wishes, though at best it "is a name given to results reached on other grounds, not a fact from which we may reason for all purposes and with respect to the rights of all parties." "64 But it is preposterous that the amount of taxes on an estate should be greater if the executors have been instructed to sell real estate than if they had been directed to transfer it directly to the beneficiaries.

As indicated above, the doctrine was used principally to reach property otherwise beyond the taxing state's "jurisdiction." Because of a statutory exemption of non-residents' intangibles, ${ }^{65}$ however, the doctrine occasionally redounded to a taxpayer's benefit by immunizing from Pennsylvania taxes local land owned by a non-resident testator who had fortuitously or by design included the magic direction to sell in his will. ${ }^{66}$ In view of the doctrine's admitted function, it may be

60. Miller v. Commonwealth, 111 Pa. 321, 2 Atl. 492 (1886); of. Drayton's Appeal, $61 \mathrm{~Pa} .172$ (1869).

61. Following Pennsylvania: In re Estate of Sanford, 188 Iowa 833, 175 N. W. 506 (1919); Land Title \& Trust Co. v. Tax Commission, 131 S. C. 192, 126 S. E. 189 (1925). Dissenters included New York, Matter of Estate of Swift, 137 N. Y. 77, 32 N. E. 1096 (1893); Maryland, State v. Fusting, 134 Md. 349, 106 Atl. 690 (1919); and Illinois, Connell v. Crosby, 210 IIl. 380,71 N. E. 350 (1904); of. McCurdy v. McCurdy, 197 Mass. 248, 83 N. E. 881 (1908); State v. Brevard, 62 N. C. 141 (1867); Northern Trust Co. v. United States, 15 A. F. T. R. 841 (E. D. Mo. 1932). See also Note (1926) 42 A. L. R. 426. A surprising wrinkle is found in In re Marx' Estate, 226 lowa 1260, 286 N. W. 422 (1939), stating that even if certain real estate "took on the form of cash as the result of sale, it still remained tangible property. Blodgett v. Silberman, 277 U. S. 1." Id. at 1265, 286 N. W. at 424.

62. On allocation of property taxes, see HANDLER, CASEs AND MATERrals ON VENDOR and Purchaser (1933) 324-38.

63. See note 58 supra. 832.

64. Pound, The Progress of the Law, 1918-1919-Equity (1920) 33 Harv. L. Rev. 813,

65. In re Small's Estate, $151 \mathrm{~Pa}$. 1, 25 Atl. 23, 27-8 (1892).

66. Coleman's Estate, $159 \mathrm{~Pa} .231,28$ Atl. 137 (1893). As a corollary to the abandonment of the doctrine as to locally owned out-of-state property after Frick v. Pennsylvania, 
surprising to note that it was unceremoniously jettisoned by the Pennsylvania courts immediately after the Supreme Court decided, in Frick v. Pennsylvania, ${ }^{57}$ that tangible property outside the state could not be included in computing death taxes. ${ }^{69}$ True, this was the first" authoritative ruling that death taxes could not ward off the Union Refrigerator Transit doctrine by a liberal application of the theory that they were imposed upon the privilege of transfer rather than on the object transferred. ${ }^{69}$ But it had long been acknowledged by the Pennsylvania courts, even without an encyclical from on high, that out-ofstate land was beyond its taxing power; and equitable conversion was regarded as compatible with that constitutional limitation..$^{70}$ The fact that the Supreme Court conferred upon tangible personalty the immunity previously enjoyed by real estate had no clear bearing on the conversion fiction..$^{13}$

Yet the doctrine's abandonment, whether under constitutional compulsion or through excessive caution, was hardly to be regretted. During its lifetime it had contributed only one more capricious element to the field of taxation. The absurdity of endowing with tax consequences

268 U. S. 473 (1925), the doctrine was also abandoned as to local property onned by a nonresident. Commonwealth v. Presbyterian Hospital, $287 \mathrm{~Pa} .49,134$ Atl. 427 (1926).

67. 268 U. S. 473 (1925).

68. In re Robinson's Estate, $285 \mathrm{~Pa} .308,312,132$ Atl. 127, 128 (1926): "Here the property involved consists of 'immovable realty' in Illinois, and, under the Fricls decision, it cannot be changed by a fiction of law into money in Pennsylvania for purpose of tasation in this state." Iowa has apparently followed Pennsylvania's lead in abandoning equitable conversion. In re Miarx' Estate, 226 Iowa 1260, 286 N. W. 422 (1939). See also 4 C. C. H. State Inheritance Estate and GifT TAx SERv. I 1605A (7th ed. 1944), for rulings by the Attorneys General of Maryland, New Hampshire and South Daliota.

69. Previously the view had been widely held that the Union Refrigerator doctrine did not apply to estate or inheritance taxes. See People v. Kellogs, 26S Ill. 489, 109 N. E. 304 (1915); In re Gumbinner's Estate, 92 Misc. 104, 155 N. Y. S. 188 (Surr. Ct. 1915); Note (1926) 42 A. L. R. 327.

70. The original Pennsylvania collateral inheritance law of 1826 taxed only property within the state, Act of April 7, 1826, Dig. PA. LAws: 1700-1830 (Purdon, 1831) 150, but in 1887 the operation of the law was expanded to embrace, inter alia, "estates situated in another State, Territory, or country, when the person, or persons, dying seized thereof, shall have their domicile within this Commonwealth. . . ." Pa. Laws 1857, No. 37, p. 79. This extension was held unconstitutional shortly after its enactment on the familiar ground that "real estate is not drawn to the domicile of the owner, for tametion or any" other purpose, and hence cannot be taxed outside of the jurisdiction where it is situate." Estate of Bittinger, $129 \mathrm{~Pa}$. 338, 345, 18 Atl. 132, 133 (1889). See also In re Vanuxem's Estate, $212 \mathrm{~Pa}$. 315, 322, 61 Atl. 876, 879 (1905): "It was not pretended that the real estate in other states could be charged with collateral inheritance tax [by Pennsylvania] as real estate, but only by reason of the fact that it was necessary for the executors to sell it, in order to provide the money to pay the pecuniary legacies." Indeed, in the Frick case itself real estate located outside Pennsylvania was excluded from the taxable estate. In re Frick's Estate, $277 \mathrm{~Pa}$. 242, 250, 121 Atl. 35, 38 (1923).

71. The Pennsylvania court went even farther in In re Paul's Estate, $303 \mathrm{~Pa} .330$, 154 Atl. 503 (1931), cert. denied, 284 U. S. 630 (1931), holding that an inheritance tax could 
such an ecoriomically neutral fact as the presence (or absence) of a direction for the sale of land was exceeded by only one thing: if the state of domicile adopted the fiction while the state of situs rejected it, the land shouldered a double tax burden, while if the situation was reversed, the transfer might go tax-free. ${ }^{72}$

Negotiable Instruments. What is the status taxwise of those types of property which, though of a representative or evidentiary character, are by commercial custom treated as valuable in themselves? ${ }^{73}$ Examples are, on the one hand, warehouse receipts, which are backed up by tangible property, and, on the other, bonds and notes, which evidence promises. For many years, bonds were held to be "in such a concrete tangible form that they are subject to taxation where found, irrespective of the domicil of the owner." 74 In rationalizing this treatment of bonds in the same fashion as railroad cars, land, or cattle, Mr. Justice Holmes argued that "a tradition which comes down from more archaic conditions," 75 accepted by "the usages and views of business men," 76 had resulted in identifying the promise to pay with the paper on which the promise was written. If then a state may tax a non-resident who keeps bonds within its boundaries, why not a similar tax when bills and notes owned by a non-resident are kept within the state? This, too, was upheld by Mr. Justice Holmes; to the argument that bills and notes were only "evidences" of the promise to pay, the loss or destruction of which would not discharge the obligation, he answered only that in modern times even a bonded indebtedness may be enforced without producing and surrendering the paper..$^{77}$ Interestingly enough, however, the doctrinal legacy from an "archaic" past which permitted negotiable instruments to be taxed like tangible property did not abridge taxability of the obligation at the owner's domicile and at the

not be levied on the unpaid purchase money for real estate which the decedent had contracted to sell during his lifetime, the deeds to which were not executed until after his death. A dissenting judge pointed out that the states where the real estate was located, New Jersey and Missouri, would apply the doctrine of equitable conversion by contract so as to free the land from death taxation. See Note (1932) 78 A. L. R. 793; Comment (1936) 46 YALE L. J. 272.

72. See Commonwealth v. Presbyterian Hospital, 287 Pa. 49, 134 Atl. 427 (9216); In re Paul's Estate, 303 Pa. 330, 154 Atl. 503 (1931); Note (1937) 46 Y ALE L. J. 687.

73. See U. S. Treas. Reg. 105, $\S 81: 50$, for the federal estate tax treatment of the property of nonresidents: ". . . [T]he written evidence of intangible personal property which is treated as being the property itself [is] within the United States if physically situated therein." For similar problems in another field, see Andrews, Situs of Intangibles for Suits Against Nonresident Claimants (1939) 49 Y ALE L. J. 741.

74. New Orleans v. Stempel, 175 U. S.' 309, 322 (1899).

75. Blackstone v. Miller, 188 U. S. 189, 206 (1903).

76. Wheeler v. Sohmer, 233 U. S. 434, 439 (1914).

77. Ibid; cf. New Orleans v. Stempel, 175 U. S. 309 (1899); Buck v. Beach, 206 U. S. 392, 403 (1907); New York ex rel. Hatch v. Reardon, 204 U. S. 152, 161 (1907). 
debtor's as well..$^{78}$ Negotiable instruments, then, enjoyed, or suffered, an ambivalent life: tangible so as to be taxable where found, intangible so as to be taxable also at the domiciles of both the owner and the debtor.

So the matter rested until the late twenties, when the Supreme Court's crusade against double taxation swept Mr. Justice Holmes' rationale into the scrapheap..$^{9}$ The Court then held that bonds were "representative and not the thing itself" and that, like other negotiable instruments, they could not be differentiated from "ordinary choses in action," ${ }^{80}$ ordinarily taxable at the owner's domicile and not elsewhere. Mr. Justice McReynolds, regarding the similarities between negotiable instruments and "tangible" property as more important than their differences, concluded that such choses in action (and, indeed, all "intangibles"), like tangibles, should be immune from taxation by more than one state. With the abandonment of the crusade against double taxation ${ }^{81}$ negotiable instruments presumably are once again subject to taxation wherever the documents themselves are found, notwithstanding the modification by the Negotiable Instruments Law of the "archaic" tradition which formerly underlay such taxability. ${ }^{82}$ And although the instruments are treated as tangible property by the state of their physical location, they are no doubt sufficiently intangible to be subjected to taxation also by the domiciles of both debtor and creditor. ${ }^{83}$

78. Kirtland v. Hotchkiss, 100 U. S. $491,498-9$ (1879): "The creditor, it is conceded, is a permanent resident within the jurisdiction of the State imposing the tax. The debt is property in his hands constituting a portion of his wealth, from which he is under the highest obligation, in common with his fellow-citizens of the same State, to contribute for the support of the government whose protection he enjoys. . . . That bond, wherever actually held or deposited, is only evidence of the debt, and if destroyed, the debt-the right to demand payment of the money loaned, with the stipulated interest-remains. Nor is the debt, for the purposes of taxation, affected by the fact that it is secured by mortgage upon real estate situated in Illinois. The mortgage is but a security for the debt. . . " See also Bonaparte v. Tax Court, 104 U. S. 592 (1881). As to the power of the debtor's state to tax, see Blackstone v. Miller, 188 U. S. 189, 205-6 (1903).

79. Blodgett v. Silberman, 277 U. S. 1, 14 (1928); Farmers Loan \& Trust Co. v. Minnesota, 280 U. S. 204 (1930).

80. Blodgett v. Silberman, 277 U. S. 1, 15 (1928); Farmers Loan \&. Trust Co. v. Minnesota, 280 U. S. 204, 209 (1930); Baldwin v. Missouri, 281 U. S. 586 (1930).

81. With the overruling of First National Bank v. Maine, 284 U. S. 312 (1932) by State Tax Commission v. Aldrich, 316 U. S. 174 (1942), it can hardly be thought that Baldwin v. Missouri. 281 U. S. 586 (1930), survives.

82. A negotiable instrument is discharged by its intentional cancellation by a holder, but a cancellation which is unintended or made by mistake or without the holder's authority is inoperative. NegotiabLe INSTRUMENTS LAW $\$ \S 119(3), 123$.

83. "It is much too late to contend that domicile alone is insufficient to give the domiciliary state the constitutional power to tax a transfer of intangibles where the owner, though domiciled within the state, keeps the paper evidences of the intangibles outside its bound- 
So much for negotiable instruments. What of documents which, though non-negotiable, are nevertheless of great commercial importance, like deeds to real estate, contracts for the purchase of land, and similar evidentiary instruments? So long as there was vitality to the tradition by which the obligation of a bond was discharged (or rendered unenforceable) by destruction of the document, there was some justification for making a distinction between a bond and a document which was only evidence of an obligation. Even though the distinction might not be of sufficient economic significance to warrant a difference in taxability, it was at least possible to say that a bond-unlike other contracts-resembled a railroad car in that the destruction of either would clearly make the owner a poorer man. But once the law had reduced bonds to the rank of "evidence," the production of which was not essential to the obligation's enforceability, retention of the distinction could adduce neither logic nor business experience in its support. If keeping a bond or promissory note within the state confers taxing jurisdiction, why should not similar consequences be attached to a. deed or a written contract for the purchase of real estate?

Yet the Court never took this step. Even Mr. Justice Holmes seemingly conceded that deeds or writings required to satisfy the Statute of Frauds would not be analogous to negotiable instruments. ${ }^{84}$ Faced squarely with the question of the taxability of non-negotiable warehouse receipts under circumstances where the warehoused property had its physical location beyond the state's borders, Mr. Justice Holmes said:

"Bonds can be taxed where they are permanently kept, because by a notion going back to very early law the obligation is, or originally was, inseparable from the paper or parchment which expressed it. . . . But a warehouse receipt does not depend upon any peculiar doctrine for its effect. .... As a key to the goods a receipt no more can be called a second property of equal value than could a key to an adamantine safe that could not be opened without it be called a second property of a value distinct from but equal to that of the money that the safe contained. . . . It cannot be assumed that a good title to the [warehoused] whiskey could not have been given while the receipts were outstanding. We assume that they made it very unlikely that it would be, but the practical probability does not make the instrument the legal equivalent of the goods." 85

Much of what Holmes says here of non-negotiable receipts would be equally true of negotiable receipts and indeed of any negotiable in-

aries." Central Hanover Bank \& Trust Co. v. Kelly, 319 U. S. 94, 96 (1943); cf. State Tax Commission v. Aldrich, 316 U. S. 174, 181-2 (1942).

84. Wheeler v. Sohmer, 233 U. S. 434, 438-9 (1914).

85. Selliger v. Kentucky, 213 U. S. 200, 204-6 (1909). 
strument, but it is reasonably apparent that, in his view, negotiability would have conferred taxability. Yet can it be seriously maintained that a taxpayer who owns negotiable warehouse receipts has received more benefits from the state of residence or that his ability to pay for the benefits he has enjoyed has been increased by the negotiability of his receipts? Conversely, is there any justification in social policy for relieving a citizen from a tax imposed by the state of his residence because he warehouses his goods in another state under non-negotiable receipts or because he so indorses his negotiable receipts as to destroy their negotiability?

Money. The uncertain fashion in which the courts have treated money furnishes a minor but nonetheless instructive instance of the unworkable distinction between tangibles and intangibles. In Blodgett v. Silberman, ${ }^{86}$ the Court held that bank notes and coin kept by a Connecticut decedent in a New York safe deposit box were "tangible property" which could not "be distinguished from the paintings and furniture held in the Frick case" 87 and hence were not subject to a Connecticut death tax. In the same case, the Court upheld the tax as applied to "bonds of the United States and certificates of indebtedness of the United States," similarly kept in a New York safe deposit box, on the ground that they "are at most choses in action and intangibles." In lumping coins and bank notes together, the court was on firm ground. Coins have intrinsic value, of course, while paper money merely attests to the deposit of metal in the Treasury or consists of promises to pay on demand. ${ }^{\$ 8}$ But there is no economic basis for differentiating one type of money from another for tax purposes, and the Legal Tender $A c t{ }^{\text {s9 }}$ has obliterated even what vestigial legal distinctions might formerly have been thought of significance. Yet if federal reserve notes are, taxwise, "tangibles" like coins and share their immunity from tax at the domicile, what sensible basis can be found for saying that the Government's promise to pay, when expressed in a bond or certificate of indebtedness, is an "intangible" and hence subject to tax at the decedent's domicile? The problem was clearly recognized by the taxpayer in Blodgett $v$. Silberman, who conceded that the bank notes "on the face show that they are only a promise by the bank or government, as the case may be, to pay gold or silver on demand," but argued that "this technical characterization as a mere promise to

86. 277 U. S. 1 (1928).

87. Frick v. Pennsylvania, 268 U. S. 473 (1925).

88. See Nussbaud, MoNey in the Law (1939) 85-7, 185-98.

89. 48 STAT. 113 (1933), 31 U. S. C. $\$ 462$ (1940). The Act provides in part that "All coins and currencies of the United States (including Federal Reserve notes and circulating notes of Federal Reserve banks and national banking associations) heretofore or hereafter coined or issued, shall be legal tender for all debts, public and private, public charges, tases, duties and dues. . . ." See Train, The Doodle Bug, in Mr. Tutr's Case Boot (1936) 305. 
pay is . . . over-ridden by common practice and recognition of these notes as the money itself." 30 This argument was apparently accepted by the court; at any rate, it vouchsafed no other reason why some governmental promises should be taxed differently from others.

The mystery thickens when one tries to find a rational basis for taxing deposit accounts differently from money in safe deposit boxes. The absurdity of doing so was pointed out long ago by Holmes, then Chief Justice of the Massachusetts Supreme Judicial Court:
". . . [I]t would be a matter for regret if a technicality having no relation to the policy of the law principally concerned should make the difference as to whether that law applied or not. If the statutes do not mean to tax identified money in the hands of a receiver when he locks it up in his box in the safety vault of a bank, natu- rally their policy would be to leave it equally untaxed if he adopted the more usual course of depositing it to a special account. To the business mind one transaction is just like the other. . . . The legal difference between the two has little or no relation to the principle of the tax." 91

Later, while on the United States Supreme Court, Holmes said that the "practical similarity [between "money in the bank and actual coin in the pocket'] more or less has obliterated the legal difference." 92 The "legal difference" was not completely obliterated, however, and twentyfive years later its vestiges were still of such potency that a bank deposit could be held to be an "intangible" with taxable situs at the owner's domicile, while bank notes and coin constituted "tangible property" taxable only at their physical location. ${ }^{93}$

More than one taxpayer, building on the "tangible" nature of money, has sought to save taxes by transactions which, though economically pointless, were thought to have legal significance. In 1935 an ingenious physician, resident in Oregon, instructed an Illinois trust company to purchase for his account $\$ 450,000$ of federal reserve notes, which he then transferred, concededly in contemplation of death, to the trust company as trustee under an irrevocable trust for the benefit of certain relatives. Later his executors, asserting that the notes were tangibles beyond the taxing jurisdiction of Oregon, resisted an Oregon tax upon their transfer in contemplation of death. Although this contention was successful in the Oregon Supreme Court, the United States Supreme Court reversed the state court, holding in Pearson v. McGrane ${ }^{94}$ that

90. Brief for Executors, p. 25, Blodgett v. Silberman, 277 U. S. 1 (1928).

91. City National Bank v. Charles Baker Co., 180 Mass. 40, 42, 61 N. E. 223, 224 (1901); cf. New Orleans v. Stempel, 175 U. S. 309, 316 (1899); Matter of Houdayer, 150 N. Y. $37,40,44$ N. E. $718(1896)$.

92. Blackstone v. Miller, 188 U. S. 189, 205 (1903).

93. Blodgett v. Silberman, 277 U. S. 1 (1928).

94. Pearson v. McGraw, 308 U. S. 313, 317 (1939). 
"the various steps in the series must be considered as constituting but one integrated and indivisible transaction." Mr. Justice Stone and Mr. Justice Frankfurter concurred on the ground "that there is nothing in the Constitution to compel a state to treat federal reserve notes for tax purposes as chattels were treated in Frick ข. Pennsyleania." os A similarly ingenious but unsuccessful scheme was under review in Van Dyke v. Wisconsin Tax Commission. ${ }^{\circ 0}$ The taxpayer, a resident of Wisconsin, went to Chicago and on demand obtained seven and a half tons of silver dollars in payment for $\$ 270,000$ in called Liberty bonds. Still in Chicago, he transferred the "tangibles" in trust for the benefit of other residents of Wisconsin. Thereafter the trustee-donees resisted a Wisconsin gift tax assessment on the ground that the gift was of "tarigibles" located outside the state. The Wisconsin Supreme Court, passing over the question of the "nature" of the silver dollars, held that this was a unitary transaction and hence taxable. The Supreme Court affirmed per curiam, ${ }^{97}$ on the authority of Pearson v. MrcGraw.

No one can quarrel with either of these decisions. Yet they leave unscathed the notions that there are differences for tax purposes between money in a safe deposit box and money in a deposit account or between the government's promise to pay when expressed on an interest-bearing instrument and its promise embodied in a non-interest bearing obligation. Consequently a state of residence cannot tax money which a taxpayer keeps in another state, so long as he hoards it in the form of cash and does not deposit it in a bank or invest it in government bonds.

\section{IV}

The doctrine of the Union Refrigerator Transit case would be difficult enough to apply if one had to do no more than determine whether a particular portion of a taxpayer's wealth is tangible or intangible property. But even after a legal taxonomist has classified property as tangible and has found that it is beyond the state's territorial boundary, there is still ample opportunity for a law suit to decide whether its absence from state $A$ is the kind of absence which bars a tax by that state and, conversely, whether its physical presence in state $B$ is, taxwise, legal presence there. The simple test of Union Refrigeralor Transit Co. v. Kentucky-is or is not the taxed property within the state's geographical boundaries?-has been qualified and complicated so as to be worthy of a lawyer's attention, though in the process the convenience of tax officer and taxpayer alike has passed into obscurity.

Moveable property poses the issue; the two leading cases involve art

95. Id. at 320 .

96. 235 Wis. 128,292 N. W. 313 (1940).

97. Van Dyke v. Wis. Tax Commission, 311 U. S. 605 (1940). 
collections lent by their owners to out of state galleries. In Frick $v$. Pennsylvania, ${ }^{98}$ the Court rejected a transfer tax imposed by Pennsylvania, the decedent's domicile, upon an art collection kept by him in New York City, in a building constructed for that purpose, on the ground that the property had its "situs" in New York and that, therefore, the transfer "occurred under and in virtue of the jurisdiction and laws" of that state exclusively. In the subsequent case of City Bank Farmers Trust Co. v. Schnader, ${ }^{99}$ the Supreme Court had to pass upon another Pennsylvania transfer tax, this time levied upon a generous resident of New York who, thinking that Pennsylvania, too, sheltered persons of aesthetic inclinations, had lent his art collection to a museum in Pennsylvania. To the argument that the pictures did not lose their New York situs by temporary absence from that state, the Supreme Court answered that the decedent "permitted the pictures to be kept and used in the Pennsylvania museum merely subject to his right at any time to order them taken to New York or elsewhere." The Court went on to hold that by sending the pictures to Pennsylvania and failing to have them returned to New York, and by "his lack of definite intention ever so to do," the decedent failed to maintain a "situs" for the pictures in New York and created one for them in Pennsylvania, thereby entitling that state to assess a death tax on their transfer. ${ }^{100}$ Presumably if the decedent had intended (or, rather, if there had been satisfactory proof of his intention) to bring the pictures back to New York, that state rather than Pennsylvania would have had exclusive power to tax the transfer at death. ${ }^{101}$

The Union Refrigerator Transit case, as suggested above, had warned of the possibility that, in disregard of the "benefit" theory, taxability of absent property by the state of its owner's domicile might depend in part upon its non-taxability elsewhere. ${ }^{102}$ That possibility might have been confined to cases of property which would otherwise go taxfree, like the ocean-going vessels involved in Southern Pacific Co. v. Kentucky ${ }^{103}$ or railroad cars which are so vagrant in their movements that they cannot be tagged for taxation by any of the states through which they pass. If immunity at the owner's domicile is to be denied to such property, both the tax officials and the taxpayer can, by an examination of relatively accessible facts, decide whether a tax is payable or

98. 268 U. S. 473 (1925).

99. 293 U. S. 112 (1934).

100. Id. at $120-1$.

101. Compare Metropolitan Life Insurance Co. v. New Orleans, 205 U. S. 395, 402 (1907): "The law may well regard the place of their [certain notes'] origin, to which they intend to return, as their true home, and leave out of account temporary absences, however long continued."

102. Supra, p. 644-5.

103. 222 U. S. 63 (1911). 
not. But the Frick and Schnader cases introduce an elusive element into the calculations of tax collectors and taxpayers alike, by basing taxability on the taxpayer's intentions with respect to his property..$^{198}$ One thinks instinctively of the unsatisfactory experience with the contemplation of death provisions of the estate taxes. ${ }^{105}$ What Randolph Paul has said in another connection of the difficulty of probing into motive is of equal applicability to the problem at hand:

". . . Too much should not be expected of the courts, for they are presented in most cases with carefully assembled evidence in proof of motive, which is a highly elusive, subjective test of taxability. ..."

"The road of exploration is always obstructed where an interested taxpayer has a monopoly of vital knowledge." 1co

Moreover, there will be little opportunity to reconcile the clash which will result when the courts of state $A$ decide that $T$ intended to confer only a temporary boon on the citizens of state $B$, with the firm purpose of bringing his art collection home, at the same time that the courts of state $B$ hold that $T$, despairing of the low cultural level in his home state $A$, unquestionably intended to keep his collection permanently in the more appreciative atmosphere of state B. ${ }^{157}$ It hardly seems necessary to point out that the benefit theory-which is the very heart of the doctrine that tangible property is taxable where located-is dismissed in cases like Frick and Schnader with indecent callousness, since the police protection afforded by the state of location (and the absence thereof in the state of the owner's house) is just as plain when the owner intends to bring his collection home as it is when he intends to leave it away from home. In these cases, protection without intent is ineffective to support the tax, while intent without protection is effective.

\section{V}

Emphasis has been placed in this article on the constitutional propriety-rather than the desirability or feasibility-of taxing tangi-

104. See Brock \& Co. v. Supervisors, 8 Cal. (2d) 286, 65 P. (2d) 791 (1937).

105. Paul, Federal Estate and Gift Taxation (1942) 243-5, 279-81; Pavenstedt, Taxation of Transfers in Contemplation of Dealh: A Proposal for Abolition (1944) 54 YaLE L. J. 70 .

106. PAUL, op. cit. supra note 105, at 279, 1124-5.

107. The unlikelihood of federal intervention to resolve conflicting determinations of such an issue as the testator's intentions with respect to particular property is indicated by Worcester County Trust Co. v. Riley, 302 U. S. 292 (1937), discussed at length by Nash, And Again Mrultiple Taxation (1938) 26 Gzo. L. J. 288. See also Tweed and Sargent, Deats and Taxes are Certain-But That of Domicile (1939) 53 Harv. L. REv. 6S; of. Texas v. Florida, 306 U. S. 398 (1939). For statutory grapplings with the problem, ere Nev Yors Tax LAW § 249-0; MAss. LAwS ANN., c. 65B (1945); Guterman, Rerilalisalion of Mrulliple State Death Taxation (1942) 42 CoL. L. REv. 1249, 1278-9. 
ble property located outside the state. The administrative machinery by which local real property taxes, the backbone of the county and municipal financial structure, ${ }^{108}$ are levied, is of course not presently equipped to assess a resident's out-of-state real property. Nor, as has been suggested, is it likely to be revamped for that purpose, even under postwar conversion plans, not only because other reforms are more urgent, ${ }^{109}$ but also because the assessment of out-of-state property would require a revolutionary departure from the fundamental conception of the real property tax as a peculiarly local levy on the real estate within the taxing district. As presently conceived, the tax has no relationship to the taxpayer's net wealth or ability to pay, ${ }^{110}$ and even property located in another taxing district within the state is not subjected to a tax by the district of the taxpayer's domicile. So long as the local real property tax retains this character, then, the constitutional "immunity" of out-of-state tangible property will as to realty be only "a handkerchief thrown over something covered by a blanket also." ${ }^{111}$ Taxes on personal property, however, are not so completely localized, and the inclusion, in computing the personal property tax, of all personal property without regard to location would not clash so violently with the underlying concept of this tax. Of course, the assessors who administer the tax could hardly be expected to exhibit more diligence in searching for out-of-state tangible property than they now show in seeking for local tangibles. ${ }^{112}$ But self-disclosure is not entirely a dead letter, and corporations, estates, trusts, and even some individuals maintain records of some accuracy by which tax returns can be verified. ${ }^{113}$ Perhaps more important are the property taxes on railroads, utilities and similar enterprises, levied on a statewide basis and centrally assessed, ${ }^{114}$ whose effective base might be enlarged if legislators were persuaded that constitutional barriers did not forbid. Such an enlargement of the base would have to take account of the

108. Bureau of the Census, Financing Federal, State, and Local, Governments: 1941 (1942) Table 5, p. 22; Bureau of the Census, Property Taxation: 1941 (1942).

109. Hansen and Perloff, State and Local Finance in the National Economy (1944) 274-83; Groves, Postwar Taxation and Economic Progress (1946) 344-8.

110. Jensen, Property Taxation in the United States (1931) 83-4; Seligaran, op. cit. supra note 17, at 19; Paddell v. City of New York, 211 U. S. 446 (1908).

111. Paul, Federac Estate and Gift Taxation (1946 Supp.) 92, quoting from Brown v. Henderson, 285 Mass. 192, 196, 189 N. E. 41, 43 (1934).

112. "Personal property ... has been found to be so unreliable and inequitable a source of public revenues that the personal property tax in most states is either a farce or a corpse." Buttenheim, Unwise Taxation as a Burden on Housing (1938) 48 YALE L. J. 240, 242; cf. People ex rel. Koester v. Board of Review, 351 Ill. 301, 184 N. E. 325 (1932); Kent, Tax Litigation in Illinois (1934) 1 U. oE CHr. L. REv. 698.

113. Compare the return which led to Northwest Airlines, Inc. v. Minnesota, 322 U. S. 292 (1944).

114. JENSEN, op. cit. supre note 110, at 415-38. 
Commerce Clause of the Federal Constitution, though under prevailing interpretations that clause does not relieve interstate commerce of the duty of "paying its own way." 115

Death taxation is not subject to the residual restrictions of the Commerce Clause. States now typically tax the intangible property of resident decedents without regard to the location of the debtors, obligors, or evidentiary instruments; and state practice prior to Frick v. Pennsylvania suggests that the legislators might prefer similarly to disregard location in taxing tangible property. Of course, it will be argued in opposition that the domiciliary state's power to tax intangibles is ancillary to its power to regulate the devolution of such property and that since it lacks the power to prescribe the devolution of out-of-state realty and tangible personalty, ${ }^{116}$ it cannot tax their transfer. ${ }^{117}$ The same type of argument has been urged against the imposition of estate and inheritance taxes by the United States and has been repeatedly rejected by the Supreme Court.118 Similarly, the view that nondomiciliary states cannot tax intangible property, because the succession thereto is controlled by the law of the domicile, is now thoroughly discredited. ${ }^{119}$ For there is no reason why principles of the conflict of

115. Western Live Stock v. Bureau of Revenue, 303 U. S. 250, 254 (1938). No attempt has been made herein to deal with the limitations upon the states' taxing powers that stem from the Commerce Clause. See Northwest Airlines v. Minnesota, 322 U. S. 292 (1944); cf. Mr. Justice Rutledge, concurring, in International Harvester Co. v. Dep't of Treasury, 322 U. S. 340, 352 et seq (1941). A recent discussion is Sutherland and Vinciguerrs, The Octroi and the Airplane (1916) 32 CoRN. L. Q. 161.

116. The devolution of land is governed by the law of the situs, Restatearest, Cos:FLICT OF LAWS (1934) § 245. While in the distribution of chattels the state of their location customarily follows the law of the decedent's domicile, it has the power to prescribe a different mode of distribution. Id. at $\$ 303$, comment $a$.

117. Compare Lowndes, Tendencies in the Taxation of Inlangibles (1930) $17 \mathrm{VA} . \mathrm{L}$. REv. 146, 153.

118. Knowlton v. Moore, 178 U. S. 41, 56-61 (1900); New York Trust Co. v. Eisner, 256 U. S. 345, 348-9 (1921). In Knosolton v. Afoore, supra at 56, the Court pointed out that there had been a federal inheritance tax as early as 1797 (1 STAT. 527), "3dopted at a time when the founders of our government and framers of our Constitution were actively participating in public affairs, thus giving a practical construction to the Constitution which they had helped to establish." In spite of judicial and legislative precedent, the notion that federal death taxation is unconstitutional dies hard. See Hearings before Sernale Finarse Committee on H. R. 8974 (Revenue Act of 1935), 74th Cong., 1st sess. (1935) 273. Current agitation for tax reduction will no doubt play upon this theme. A straw in the wind is Committee on Postwar Tax Policy, A Tax Progran for a Solvent Auserica (1945) 163.

119. The argument was advanced by Mr. Justice Stone, concurring, and answered by Mr. Justice Holmes, dissenting, in Farmers Loan \& Trust Co. v. Minnesota, 280 U. S. 204, 214, 216 (1930). Within a few months Mr. Justice Stone showed that he would apply the doctrine only within narrow limits, Baldwin v. Missouri, 281 U. S. 586 (1930), while the then majority gave it full rein. See First National Bank v. Maine, 284 U.S. 312 (1932). For the current view, recognizing that, even if the law of the domiciliary state controls the transfer, it does so only by the grace of the non-domiciliary state, see State Tax Commission v. Aldrich, 316 U. S. 174 (1942); cf. Mr. Justice Holmes, in Blackstone v. Miller, 188 U. S. 
laws which were evolved to mediate between conflicting schemes for the transmission of wealth at death should be employed to regulate the tax practices of the several states. ${ }^{120}$ It is evident that confusion would result if there were no way of harmonizing clashing rules for the descent of the same property interest; no such confusion attends the imposition of taxes by several sovereigns when the owner has enjoyed privileges, benefits or protection in each, except in the unusual case when the property is insufficient to meet all claims against it."121 "The simple but controlling question is whether the state has given anything for which it can ask return." 122 Of course, the mere fact that multiple death taxation is constitutionally impeccable does not mean that it is socially desirable. Many states, feeling that they should yield to the domiciliary state, have enacted reciprocal exemption statutes, ${ }^{123}$ and it may be that ultimate solution of the problem of multiple death taxation will be found in a relinquishment of claims by non-domiciliary states, either unilaterally by enactment of such statutes or by joint action in the form of interstate compacts. ${ }^{124}$ One advantage of vesting the domiciliary state with jurisdiction over the entire estate, without regard to location, is that it would prevent violation of the progressive principle through splitting the tax brackets, a loophole which can be only partially closed with existing devices. ${ }^{125}$ Another route to the same result would be a single federal system of death taxation, in the revenue from which the states would share according to formula. ${ }^{120}$ In

189, 205-6 (1903): "What gives the debt [bank deposit] validity? Nothing but the fact that the law of the place where the debtor is will make him pay. . . . To test it, suppose that New York should turn back the current of legislation and . . . provide that all debts hereafter contracted in New York and payable there should be extinguished by the death of either party. Leaving constitutional considerations on one side, it is plain that the right of the foreign creditor would be gone."

120. See Cahn, Time, Space, and Estate Tax (1941) 29 Geo. L. J. 677, 696. For the extent to which tax laws, willy-nilly, regulate the transmission of wealth, see Cahn, Federal Regulation of Inheritance (1940) U. OF PA. L. REv. 297.

121. Cf. Texas v. Florida, 306 U. S. 398 (1939).

122. Wisconsin v. J. C. Penney, 311 U. S. 435, 444 (1940).

123. See note 30 supra.

124. See Mr. Justice Frankfurter, concurring, State Tax Commission v. Aldrich, 316 U. S, 174, 184 (1942); Frankfurter and Landis, The Compact Clause of the Constitution-A Study in Interstate Adjustments (1925) 34 YALE L. J. 685, 704.

125. Maxwell v. Bugbee, 250 U. S. 525 (1919); $c f$. Lowndes, Rate and Measure in Jurisdiction to Tax-Aftermath of Maxzell v. Bugbee (1936) 49 Harv. L. Rev. 756. For a related problem, see Perkins, State Action Under the Federal Estate Tax Credit Clause (1935) 13 N. C. L. REv. 271, 282-3.

126. Hellerstein and Hennefeld have pointed out that the Supreme Court is not equipped to settle the very real conflicts between the taxing powers and revenue needs of the several states on the one hand and the requirements of a unified national economy on the other, and they have coupled with their critical analysis a battery of legislative proposals. See State Taxation in a National Economy (1941) 54 HARv. L. REv. 949; and of. Rodell, sipra note 1 , at 1181-5. See also the comprehensive program of the Committee on Intergovern- 
any event, the remedy for multiple taxation should not be sought in the Fourteenth Amendment, and the states should be free to adopt whatever treatment for out-of-state tangible property seems desirable, without being coerced by constitutional bugbears which have already been rejected as to intangible property and which have no greater validity as applied to tangibles.

mental Fiscal Relations, SEN. Doc. No. 69, 78th Cong., 1st Sess. (1943) 14-6, 235-8, 241, 469-96, discussed by Maxifeli, The Fiscal Ispact of Federalisa in tae UNited States (1946) 350-3, and, in a more limited field, the recommendations of the Civil Acronatics Board, H. R. Doc. No. 141, 79th Cong., 1st Sess. (1945). Parallel problems in the internstional sphere are dealt with by Bloch and Heilemann, International Tox Relations (19:6) 55 Yale L. J. 1158; Bailey, Double Taxation in Regard to Deafls Dulies (1945) 27 J. CousP. LEG. \& INT. L., pts. III-IV, p. 46. 